\title{
Effect of Anthropogenic Activities on Surface and Ground Water in Ogwuama Community of Ahiazu, IMO State, Nigeria
}

\author{
Tochukwu Ezechi Ebe ${ }^{1}$, Roseline Feechi Njoku-Tony ${ }^{2}$, Ihejirika C. E. ${ }^{3}$, Emereibeole E ${ }^{4}$ I., Nicholas \\ Chima Ndukwu ${ }^{5}$, Mgbemena I. C. ${ }^{6}$ And Augusta Anuli Nwachukwu ${ }^{7}$ \\ 1, 2, 3, 4 and 5 Department of Environmental Technology, School of Environmental Sciences, \\ Federal University of Technology, Imo State, Nigeria.

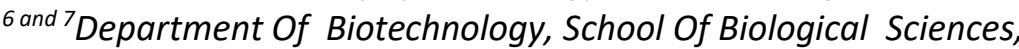 \\ Federal University Of Technology, Imo State, Nigeria. \\ akumziri@gmail.com
}

\begin{abstract}
Human activities have become a major source of environmental pollution especially on the issue of water pollution which includes surface and ground water. This research was aimed at studying the effect of human activities such as indiscriminate defecation, fermentation of cassava tubers etc on the water quality of Onuakpaka stream and selected ground water in Ogwuama community of Ahiazu, Imo State, Nigeria. Water samples were collected in triplicates each with sterile containers from upstream, downstream and ground water. All the samples were analyzed using standard method. The result showed that the $\mathrm{pH}$ of samples collected from the upstream and downstream were more acidic (5.70 and 5.90 respectively) than the ground water (6.06). Also, the upstream and downstream have high turbidity of 14.76 and 15.40 respectively. More also, dissolved oxygen in the stream samples were below the World Health Organization and Federal Ministry of Environment standards while the ground water samples were within the standard. Also there were presence of feacal counts and Escherichia coli in all the samples collected (8.00 in ground water, 13.00 in the upstream and 23.00 downstream) this may be due to indiscriminate defecation. Furthermore, the temperature, conductivity, total dissolved oxygen etc were within the standard in all the samples collected. Conclusively, the presence of feacal contaminant and Escherichia coli signifies that the water is highly polluted and unfit for drinking and domestic work. This posses a great danger to human health in this community.
\end{abstract}

Keywords: contamination, anthropogenic, upstream, downstream, ground water.

\section{Introduction}

Water is very important in our day to day activities. Sources of water in Ogwuama community are stream and ground water. Water is a scarce and fading resource and its management can have an impact on the flow and the biological quality of rivers and streams. The quality of water source is influenced majorly by anthropogenic activities. Such as cassava fermentation and intensive agricultural practice, washing of cloths, bathing, defecation and discharge of massive amount of waste around the 
water source. The impact of these anthropgenic activities has been so extensive that the water bodies have lost their significant capacity to a large extent.

The quality of water is determined by monitoring microbial load especially feacal coliform and physicochemical parameters like $\mathrm{pH}$, Dissolved oxygen, Biochemical oxygen demand etc. The problem of ground water contamination include outbreaks of water-borne diseases, as well as unsuitability of water for both agricultural and domestic uses. Low water tables may cause low infiltration rates.

\section{Materials and Method}

\subsection{Study Area}

Ogwuama in Ahiazu Mbaise, Imo State of Nigeria is located within $7^{\circ} 14^{\prime} 348^{\prime \prime}$ to $7^{\circ} 18^{\prime} 44^{\prime \prime}$ E and $5^{\circ} 31^{\prime}$ $006^{\prime \prime}$ to $5^{\circ} 35^{\prime} 56^{\prime \prime} \mathrm{N}$. The climate of the area is humid tropical and typifies the rain forest zone of the equatorial region. Mean ambient temperature is $28^{\circ} \mathrm{C}$. Wet season last between April to November with a short dry season lasting the rest of year.

\subsection{Sample Collection}

Water samples were randomly collected from Onuakpaka stream using $500 \mathrm{ml}$ sterile containers at three different points on the upstream and downstream and from three different public groundwater using standard method.

\subsection{3 Determination of Physico-Chemical Parameters}

The $\mathrm{pH}$, temperature, conductivity, total dissolved solid and dissolved oxygen were determined in-situ using jenway(Hanna 1910) multipurpose tester in each sampling point while the BOD was determined using a winkler method for a period of five days at $20^{\circ} \mathrm{C}$.

Also, the turbidity was determined by photometric method using $\mathrm{HACH}$ DR/2010 spectrometer at a wavelength of $860 \mathrm{~nm}$.

More also, Argentometric method described by APHA (2005) was used to determine the chloride content.

EDTA titrimetric method was used to determine total hardness.

Nitrate was determine by cadmium reduction method using $\mathrm{H} 183200$ multiparameter bench photometer at a wavelength of $525 \mathrm{~nm}$.

\subsection{Microbial Analysis of Samples}

Samples were serially diluted and aliquots of $0.1 \mathrm{ml}$ of each water sample was used to inoculated on plate, Eosin methylene blue agar and potato dextrose agar nutrient were added by spread plate method. These plates were then incubated at $37^{\circ} \mathrm{C}$ for $24 \mathrm{hrs}$ for bacteria Colonies and $25^{\circ} \mathrm{C}$, $78 \mathrm{hrs}-$ $120 \mathrm{hrs}$ for fungi Colonies. After incubation, colonies were identified, counted and recorded. 
Tochukwu Ezechi Ebe, Roseline Feechi Njoku-Tony, Ihejirika C. E., Emereibeole E. I., Nicholas Chima Ndukwu, Mgbemena I. C. and Augusta Anuli Nwachukwu; Effect of Anthropogenic Activities on Surface and Ground Water in Ogwuama Community of Ahiazu, IMO State, Nigeria. Journal of Biomedical Engineering and Medical Imaging, Volume 5, No 3, June (2018), pp -27-33

\section{Results and Discussion}

\subsection{Results}

A total of 9 samples were collected (three samples each from the upstream, downstream and ground water).

Table 1: The physico-chemical and microbial analysis results of well water.

\begin{tabular}{|c|c|c|c|c|c|c|}
\hline Parameter & $\begin{array}{l}\text { FMEMV } \\
\text { Standard }\end{array}$ & $\begin{array}{c}\text { WHO } \\
\text { Standard } \\
(2008)\end{array}$ & $\begin{array}{l}\text { Ground } \\
\text { water } 1\end{array}$ & $\begin{array}{l}\text { Ground } \\
\text { water } 2\end{array}$ & $\begin{array}{l}\text { Ground } \\
\text { water } 3\end{array}$ & $\begin{array}{l}\text { Mean } \\
\text { value }\end{array}$ \\
\hline $\mathrm{pH}$ & $6.5-8.5$ & $6.5-9.5$ & 6.06 & 6.07 & 6.05 & 6.06 \\
\hline Temp $\left({ }^{\circ} \mathrm{C}\right)$ & $20-30$ & $\mathrm{~N} / \mathrm{A}$ & 26 & 28 & 27 & 27 \\
\hline $\begin{array}{l}\text { Conductivity } \\
\text { (Us/cm) }\end{array}$ & 100 & 100 & 109 & 111 & 107 & 109 \\
\hline Turbidity (NTU) & 10 & 5 & 0.00 & 0.00 & 0.00 & 0.00 \\
\hline $\mathrm{DO}(\mathrm{mg} / \mathrm{l})$ & $>4$ & 4 & 4.18 & 4.20 & 4.22 & 4.20 \\
\hline BOD (Mg/l) & 10 & 6 & 1.8 & 2.1 & 2.1 & 2.0 \\
\hline $\begin{array}{l}\text { Total Dissolved } \\
\text { solid(mg/l) }\end{array}$ & 250 & 250 & 70.87 & 70.85 & 70.83 & 70.85 \\
\hline $\begin{array}{l}\text { Total } \\
\text { Chloride(mg/l) }\end{array}$ & 250 & 250 & - & 145.08 & 145.10 & 145.08 \\
\hline $\begin{array}{l}\text { Total } \\
\text { Hardness }(\mathrm{mg} / \mathrm{l})\end{array}$ & 200 & 200 & 145.06 & 2.1 & 2.4 & 2.3 \\
\hline Nitrate $(\mathrm{mg} / \mathrm{l})$ & 40 & 45 & 22.88 & 22.93 & 22.89 & 22.90 \\
\hline $\begin{array}{l}\text { Total faecal count } \\
\text { (cfu) }\end{array}$ & 0 & $\mathrm{~N} / \mathrm{A}$ & 9 & 11 & 10 & 10 \\
\hline $\begin{array}{l}\text { Total E-Coli } \\
\text { Count(cfu) }\end{array}$ & 0 & $\mathrm{~N} / \mathrm{A}$ & 9 & 9 & 6 & 8 \\
\hline
\end{tabular}

$\mathrm{N} / \mathrm{A}=\quad$ Not Available 
Table 2: The physico-chemical and microbial analysis results of Upstream.

\begin{tabular}{|c|c|c|c|c|c|c|}
\hline Parameter & $\begin{array}{l}\text { FMEMV } \\
\text { Standard }\end{array}$ & $\begin{array}{c}\text { WHO } \\
\text { Standard } \\
(2008)\end{array}$ & Upstream 1 & Upstream 2 & Upstream 3 & Mean value \\
\hline $\mathrm{pH}$ & $6.5-8.5$ & $6.5-9.5$ & 5.71 & 6.69 & 5.70 & 5.70 \\
\hline Temp $\left({ }^{\circ} \mathrm{C}\right)$ & $20-30$ & $\mathrm{~N} / \mathrm{A}$ & 27 & 27 & 27.3 & 27.1 \\
\hline $\begin{array}{l}\text { Conductivity } \\
\text { (Us/cm) }\end{array}$ & 100 & 100 & 8 & 10 & 12 & 10 \\
\hline Turbidity (NTU) & 10 & 5 & 14.65 & 14.30 & 15.33 & 14.76 \\
\hline $\mathrm{DO}(\mathrm{mg} / \mathrm{l})$ & $>4$ & 4 & 3.57 & 3.55 & 3.68 & 3.60 \\
\hline $\mathrm{BOD}(\mathrm{Mg} / \mathrm{l})$ & 10 & 6 & 2.4 & 2.0 & 1.99 & 2.1 \\
\hline $\begin{array}{l}\text { Total Dissolved } \\
\text { solid(mg/l) }\end{array}$ & 250 & 250 & 6.00 & 6.40 & 7.10 & 6.50 \\
\hline $\begin{array}{l}\text { Total } \\
\text { Chloride(mg/l) }\end{array}$ & 250 & 250 & 65.9 & 70.0 & 82.81 & 72.9 \\
\hline $\begin{array}{l}\text { Total } \\
\text { Hardness(mg/l) }\end{array}$ & 200 & 200 & 0.5 & 0.6 & 0.7 & 0.6 \\
\hline Nitrate(mg/l) & 40 & 45 & 10.97 & 10.90 & 10.83 & 10.90 \\
\hline $\begin{array}{l}\text { Total faecal count } \\
\text { (cfu) }\end{array}$ & 0 & $\mathrm{~N} / \mathrm{A}$ & 22 & 22 & 22 & 22 \\
\hline $\begin{array}{l}\text { Total E-Coli } \\
\text { Count(cfu) }\end{array}$ & 0 & $\mathrm{~N} / \mathrm{A}$ & 9 & 12 & 18 & 13 \\
\hline
\end{tabular}

$\mathrm{N} / \mathrm{A}=$ Not Available

Table 3: The physico-chemical and microbial analysis results of downstream.

\begin{tabular}{|c|c|c|c|c|c|c|}
\hline Parameter & $\begin{array}{l}\text { FMEMV } \\
\text { Standard }\end{array}$ & $\begin{array}{c}\text { WHO } \\
\text { Standard } \\
(2008)\end{array}$ & $\begin{array}{l}\text { Down- } \\
\text { stream } 1\end{array}$ & $\begin{array}{l}\text { Down- } \\
\text { stream } 2\end{array}$ & $\begin{array}{l}\text { Down- } \\
\text { stream } 3\end{array}$ & Mean value \\
\hline $\mathrm{pH}$ & $6.5-8.5$ & $6.5-9.5$ & 5.80 & 5.90 & 6.00 & 5.90 \\
\hline Temp ( $\left.{ }^{\circ} \mathrm{C}\right)$ & $20-30$ & $\mathrm{~N} / \mathrm{A}$ & 27.1 & 27.3 & 27.5 & 27.3 \\
\hline $\begin{array}{l}\text { Conductivity } \\
\text { (Us/cm) }\end{array}$ & 100 & 100 & 11 & 11 & 14 & 12 \\
\hline Turbidity (NTU) & 10 & 5 & 15.48 & 15.60 & 16.14 & 15.74 \\
\hline $\mathrm{DO}(\mathrm{mg} / \mathrm{l})$ & $>4$ & 4 & 3.57 & 3.80 & 3.85 & 3.80 \\
\hline $\mathrm{BOD}(\mathrm{Mg} / \mathrm{l})$ & 10 & 6 & 0.79 & 0.70 & 0.61 & 0.70 \\
\hline $\begin{array}{l}\text { Total Dissolved } \\
\text { solid( } \mathrm{mg} / \mathrm{l})\end{array}$ & 250 & 250 & 7.10 & 7.60 & 8.70 & 7.80 \\
\hline $\begin{array}{l}\text { Total } \\
\text { Chloride(mg/l) }\end{array}$ & 250 & 250 & 150 & 172.6 & 224 & 182.2 \\
\hline $\begin{array}{l}\text { Total } \\
\text { Hardness(mg/l) }\end{array}$ & 200 & 200 & 0.65 & 0.70 & 0.75 & 0.70 \\
\hline Nitrate(mg/l) & 40 & 45 & 0.36 & 0.28 & 0.26 & 0.30 \\
\hline $\begin{array}{l}\text { Total faecal count } \\
\text { (cfu) }\end{array}$ & 0 & $\mathrm{~N} / \mathrm{A}$ & 28 & 40 & 52 & 40 \\
\hline $\begin{array}{l}\text { Total E-Coli } \\
\text { Count(cfu) }\end{array}$ & 0 & $\mathrm{~N} / \mathrm{A}$ & 20 & 22 & 27 & 23 \\
\hline
\end{tabular}

$\mathrm{N} / \mathrm{A}=$ Not Available 
Tochukwu Ezechi Ebe, Roseline Feechi Njoku-Tony, Ihejirika C. E., Emereibeole E. I., Nicholas Chima Ndukwu, Mgbemena I. C. and Augusta Anuli Nwachukwu; Effect of Anthropogenic Activities on Surface and Ground Water in Ogwuama Community of Ahiazu, IMO State, Nigeria. Journal of Biomedical Engineering and Medical Imaging, Volume 5, No 3, June (2018), pp -27-33

Table 4: The mean standard deviation of the water samples

\begin{tabular}{|l|c|c|c|c|}
\hline Parameters & FMENV Std & Well water & Up stream & Down stream \\
\hline $\mathrm{pH}$ & $6.5-8.5$ & $6.06 \pm 0.01$ & $5.70 \pm 0.01$ & $5.90 \pm 0.10$ \\
\hline Temp ( $\left.{ }^{\circ} \mathrm{C}\right)$ & $20-30$ & $27.00 \pm 1.00^{\mathrm{a}}$ & $27.10 \pm 0.17^{\mathrm{a}}$ & $27.30 \pm 0.20^{\mathrm{a}}$ \\
\hline $\begin{array}{l}\text { Conductivity } \\
(\text { Us/cm) }\end{array}$ & 100 & $109.00 \pm 2.00^{\mathrm{b}}$ & $10.00 \pm 2.00^{\mathrm{b}}$ & $12.00 \pm 1.73^{\mathrm{b}}$ \\
\hline Turbidity (NTU) & 10 & $0.00 \pm 0.00$ & $14.76 \pm 0.52$ & $15.74 \pm 0.35$ \\
\hline $\mathrm{DO}(\mathrm{mg} / \mathrm{l})$ & $>4$ & $4.20 \pm 0.02$ & $3.60 \pm 0.07$ & $3.80 \pm 0.05$ \\
\hline BOD (Mg/l) & 10 & $2.00 \pm 0.17$ & $2.13 \pm 0.23$ & $0.70 \pm 0.09$ \\
\hline $\begin{array}{l}\text { Total Dissolved } \\
\text { solid(mg/l) }\end{array}$ & 250 & $70.85 \pm 0.02^{\mathrm{c}}$ & $6.50 \pm 0.56^{\mathrm{c}}$ & $7.80 \pm 0.82^{\mathrm{c}}$ \\
\hline $\begin{array}{l}\text { Total } \\
\text { Chloride(mg/l) }\end{array}$ & 250 & $145.08 \pm 0.02^{\mathrm{d}}$ & $72.90 \pm 8.82^{\mathrm{d}}$ & $182.20 \pm 3.02^{\mathrm{d}}$ \\
\hline $\begin{array}{l}\text { Total } \\
\text { Hardness(mg/l) }\end{array}$ & 200 & $2.30 \pm 0.17$ & $0.60 \pm 0.10$ & $0.70 \pm 0.05^{\circ}$ \\
\hline Nitrate(mg/l) & 40 & $22.90 \pm 0.03^{\mathrm{e}}$ & $10.90 \pm 0.07^{\mathrm{e}}$ & $0.30 \pm 0.05^{\mathrm{e}}$ \\
\hline $\begin{array}{l}\text { Total faecal count } \\
\text { (cfu) }\end{array}$ & 0 & $10.00 \pm 1.00^{\mathrm{f}}$ & $22.00 \pm 0.00^{\mathrm{f}}$ & $40.00 \pm 5.00^{\mathrm{f}}$ \\
\hline $\begin{array}{l}\text { Total E-Coli } \\
\text { Count(cfu) }\end{array}$ & 0 & $8.00 \pm 1.73^{\mathrm{g}}$ & $13.00 \pm 4.58^{\mathrm{h}}$ & $23.00 \pm 2.65^{\mathrm{g}} \mathrm{h}$ \\
\hline
\end{tabular}

Values are mean \pm Standard deviation of triplicate determinations values bearing the same superscript "a,b,c,d,e,f,g,h" across the same row are significantly different $(p<0.05)$.

\subsection{Discussion}

The mean $\mathrm{pH}$ values recorded showed that ground water, upstream and downstream waters are slightly acidic and below the lower permissible limit recommended by WHO and FMENV. This may be due to the organic contamination which may come from natural leachates, atmospheric droplets and human contamination during fermentation of cassava in the water. Also caustic soda from soap and detergent during washing of cloths and bathing in the stream may be the cause of low pH as recorded in Ekhaise and Anyasi (2005).

The mean temperature of the water samples collected was within the permissible limit. Also Ekhaise and Anyasi (2005) reported that change in temperature difference of any aquatic habitat is affected by weather, the extent of shade from direct exposure to sunlight or biodegradation of organic matter that enter the water.

The mean values of conductivities of ground water is a little bit higher than WHO/FMENV limits while that of upstream and downstream waters are lower, though the waters can be suitable for domestic uses. The high conductivity value in the ground water may be due to high total dissolved solid as found in Akubugwu and Duru (2011).

Turbidity in drinking water is caused by particulate matter that may be present from water source as a consequence of inadequate filtration. From the mean values of turbidity of the waters, ground water is below the permissible limits while that of upstream and downstream waters were above the permissible limits and can shield the pathogenic organisms. Therefore, the higher the turbidity, the more energy and chemicals required for water treatment (Obasi et al., 2004). 
The mean value of Dissolved Oxygen (DO) of ground water was within the limit of FMENV and a little bit higher than the WHO while that of upstream and downstream water are a little bit below the limit values recommended by WHO/FMENV and therefore can support aquatic life (Njoku-Tony et al., 2016). Though, Ukaga and Onyeka (2002) stated that the desirable range of dissolved oxygen for normal fish growth is between 5.5 to $7.8 \mathrm{mg} / \mathrm{L}$.

The total dissolved solid is indicative of material carried in solid form and this falls within the WHO/FMENV standards.

In Tables 1, 2 and 3 the mean chloride are $145.8 \mathrm{mg} / \mathrm{L}, 72.9 \mathrm{mg} / \mathrm{L}$ and $182.2 \mathrm{mg} / \mathrm{L}$ which are quite lower than the WHO/FMENV limit of $250 \mathrm{mg} / \mathrm{L}$, the chloride of the upstream water was relatively higher than that of the ground water and downstream water which do not pose any health risk (WHO, 2011).

The water samples foam easily with soap. Comparatively, the upstream water sample had the lowest value of $0.6 \mathrm{mg} / \mathrm{L}$ and will produce lather with soap easier than the downstream and ground water. The direct effect of hardness on human health is yet to be proven scientifically (Sharma and Chandel, 2004). Hardness is not a health concern but can cause mineral build-up in plumbing fixtures and poor foaming of soap and detergents (WHO, 2011).

From the mean values of Nitrate in Table 4 recorded lower compared with WHO and FMENV limits. This means that the nitrate levels of the three water samples do not pose any health threat. High concentration of nitrate in both surface and shallow groundwater can be probably due to poor sanitation and latrine construction, fertilizer and other agrochemical use and causes methemoglobinemia in children (Margaret et al., 2012).

The BOD values fall within the WHO standard. According to Moore and Moore (1976), BOD values of 1-2 $\mathrm{mg} / \mathrm{L}$ was classified as clean water, $2-3 \mathrm{mg} / \mathrm{L}$ as fairly clean water, $4-5 \mathrm{mg} / \mathrm{L}$ as fairly polluted water and $10 \mathrm{mg} / \mathrm{L}$ as bad and polluted water. Therefore, the ground water and upstream can be classified as fairly clean water while the downstream can be classified as clean water.

Results of the heterotrophic bacterial count showed that the ground water had the lowest load. This is simply a measure of the number of live bacteria present in water and does not necessarily indicate health threats. Faecal coliform bacteria were detected in all the waters but were a bit much in the downstream water. According to FMENV standards, drinking water should have zero faecal coliform bacterial count in $100 \mathrm{ml}$ of the water. It is most likely that faecal contamination arises from human activities. The mean values of $E$. coli detected $\left(0.8 \times 10^{1} \mathrm{Cfu} / \mathrm{ml}\right)$ in the ground water, $\left(1.3 \times 10^{1} \mathrm{cfu} / \mathrm{ml}\right)$ in the upstream water and $\left(2.3 \times 10^{1} \mathrm{cfu} / \mathrm{ml}\right)$ in the downstream water. $E$. coli is normally a harmless commensal in the alimentary canal of a man and other animals. However, some sero-types frequently cause gastroenteritis characterized by severe diarrhea with mucus or blood and with dehydration but usually without fever. Children, especially the newborn are usually affected but increasing cases of adult diarrhea caused by E. coli are also being noted (Okafor, 1985). Therefore, the presence of E. coli in the waters makes it potential health risk to its consumers.

\section{Conclusion}

Due to the heavy bacterial load, the water sampled were not good drinking and for other domestic activities. There is need to reduce most anthropogenic activities around the water source especially 
Tochukwu Ezechi Ebe, Roseline Feechi Njoku-Tony, Ihejirika C. E., Emereibeole E. I., Nicholas Chima Ndukwu, Mgbemena I. C. and Augusta Anuli Nwachukwu; Effect of Anthropogenic Activities on Surface and Ground Water in Ogwuama Community of Ahiazu, IMO State, Nigeria. Journal of Biomedical Engineering and Medical Imaging, Volume 5, No 3, June (2018), pp -27-33

those that have negative impact on the water body such as defecation (both humans and animals), fermentation etc. This will help to improve the sanitization of water for domestic use since the stream and ground water are the major source of water in this area. Furthermore, sinking of shallow borehole should be discouraged.

\section{REFERENCES}

[1] Akubugwo E. I. and Duru M. K. C. (2011). Human Activities and Water Quality: a case study of Otamiri River, Owerri, Imo State Nigeria. Global Research Journal of Science. 1: 48-53

[2] APHA (2005). Standard Methods for the Examination of Water and Wastewater. $21^{\text {st }}$ ed. American Public Health Association. Washington DC. 46.

[3] Ekhaise F. O. and Anyasi C. C. (2005). Influence of Breweries Effluent Discharge on the Microbiological and Physico-chemical Quality of Ikpoba River, Nigeria. African Journal of Biotechnology. 4(10): 1062-1065.

[4] Moore W. T. and Moore E. A. (1976). Environmental Chemisty. Academic Press London. 360-368.

[5] Margaret M., Nancy M. T., Keith S. P. and Robert J. N. (2012). Nitrate: Health Effects in Drinking Water. Natural Resources; Cornell cooperative Extension. www.psep.ice.cornell.edu.

[6] Njoku-Tony R. F., Ebe T. E., Ihejirika C. E., Ejiogu C. C. and Uyo C. N. (2016). Assessment of Physico-chemical and Microbial Load of Nworie River, Owerri, Imo State, Nigeria. Journal of Mobile Computing and Application. 3(1): 29-37.

[7] Obasi R. A, Balogun O. and Ajayi O. (2004). The Physico-chemical Investigation of River I rejo, Ekiti State, Nigeria. Journal of Applied Science. 7(2): 4121-4334.

[8] Okafor N. (1985). Aquatic and Water Microbiology. Fourth Dimension Publishing Ltd., Enugu p. 87.

[9] Sharma S. K. and Chandel (2004).Groundwater Pollution and Evaluation of Physico-chemical Properties of Groundwater. Environmental and Ecology 2 (2):319-324.

[10] Ukaga C. N. and Onyeka P. I. K. (2002). Aquarium and Hydrobiology Techniques in Biology. $1^{\text {st }}$ ed. Optimal International Ltd, Enugu. Pp 144-149.

[11] WHO, (2011). Guidelines for Drinking Water Quality. Geneva.

[12] WHO, (2008). Guideline for Drinking Water Quality.First Addendum to third Edition. World Health Organisation, Geneva. 515. 